\title{
Pemodelan Waktu Survival Pekerja dengan Menggunakan Regresi Cox Proportional Hazard
}

\author{
Nadia Rahma Nur Insyira, R. Mohamad Atok, dan Imam Safawi Ahmad \\ Departemen Statistika, Fakultas Matematika, Komputasi dan Sains Data, \\ Institut Teknologi Sepuluh Nopember (ITS) \\ e-mail:safawi@statistika.its.ac.id
}

\begin{abstract}
Abstrak-Kematian merupakan peristiwa yang tidak dapat diperkirakan waktu kejadiannya sehingga dapat dialami oleh semua orang. Kematian dapat disebabkan oleh berbagai macam faktor, dalam penelitian ini diduga ada lima faktor yang mempengaruhi kematian seorang pekerja atau Aparatur Sipil Negara (ASN). Penelitian ini bertujuan untuk mengetahui model survival yang terjadi pada kematian seorang pekerja Aparatur Sipil Negara (ASN). Faktor-faktor yang diduga mempengaruhi kematian seorang pekerja akan dimodelkan dengan waktu ketahanan hidup (waktu survival), sehingga akan diketahui faktor-faktor mana saja yang berpengaruh secara signifikan terhadap waktu survival pekerja. Pada penelitian ini akan dilakukan pendekatan dengan metode bootstrap, yang merupakan pengambilan sampel secara random berdasarkan data asli sehingga akan didapatkan parameter-parameter yang signifikan dengan melakukan pengujian confidence interval. Berdasarkan analisis ini dengan memasukkan semua variabel, hasil Kaplan-Meier menunjukkan menurun sampai rentang waktu 40 tahun. Pengujian log-rank menunjukkan variabel jenis kelamin dan anak tidak ada perbedaan secara signifikan antara kurva survival disetiap kelompoknya. Berbeda dengan variabel golongan pekerja dan pasangan diketahui bahwa variabel tersebut memiliki perbedaan kurva survival antar kelompoknya. Pemodelan regresi cox proportional hazard menghasilkan variabel golongan 4 dan pasangan yang berpengaruh secara signifikan terhadap waktu survival pekerja.
\end{abstract}

Kata Kunci-Kematian, Kaplan_Meier, Log-Rank, Pekerja, Regresi Cox Proportional Hazard.

\section{PENDAHULUAN}

$\mathrm{K}$ EMATIAN merupakan peristiwa dimana semua orang tidak dapat memperkirakan waktu kejadiannya, sehingga hal ini dapat dialami oleh semua orang dari semua golongan. Arti kematian itu sendiri adalah berakhirnya fungsi biologis tertentu sehingga hal ini menjadi tanda-tanda seseorang dianggap mengalami peristiwa kematian [1].

Pada penelitian ini akan diteliti tentang faktor-faktor penyebab kematian pada data pekerja Pegawai Negeri Sipil. Data ini tercatat sebagai data pensiun meninggal aktif di PT. Taspen Kantor Cabang Utama Surabaya. Data pensiun meninggal aktif merupakan data yang dicatat ketika seorang keluarga peserta pensiun melakukan klaim meninggal sebelum memasuki waktu pensiun. Faktor-faktor yang diduga mempengaruhi kematian pekerja adalah jenis kelamin pekerja, golongan pekerja, pasangan pekerja, anak pekerja, dan usia pekerja. Variabel dependen dalam penelitian ini adalah masa kerja seorang pekerja. Sedangkan untuk variabel independennya adalah jenis kelamin pekerja, golongan pekerja, pasangan pekerja, anak pekerja dan usia. Variabelvariabel tersebut digunakan untuk mencari faktor mana saja yang mempengaruhi pekerja meninggal.

Terpilihnya variabel jenis kelamin sebagai salah satu pendugaan yang mempengaruhi pekerja meninggal karena berdasarkan data yang sudah diterbitkan oleh World Health Organization (WHO) usia angka harapan hidup wanita lebih panjang daripada pria. Faktor lainnya yang menyebabkan kematian adalah tuntutan pekerjaan yang tinggi dapat menyebabkan stres sehingga dapat menimbulkan gangguan kesehatan dan berujung pada kematian. Hal ini ditunjukkan dengan penelitian Indiana University Kelley School of Business yang menunjukkan bahwa jika seseorang berada pada tuntutan pekerjaan yang tinggi maka resiko meninggal akan lebih besar $15,4 \%$ daripada tidak [2]. Faktor lainnya yang dapat mempengaruhi kematian adalah jumlah anggota keluarga yang terlalu banyak. Riset yang dilakukan Maria Chiu dari Institute for Clinical Evaliative Sciences di Toronto mengenai resiko ayah tunggal meninggal tiga kali lipat lebih tinggi daripada ibu tunggal dan ayah berpasangan [3]

Pada penelitian ini akan dilakukan pemodelan regresi cox proportional hazard dimana model ini akan menggambarkan waktu survival pekerja dari lama seseorang bekerja sampai meninggal dengan faktor-faktor yang diduga mempengaruhi waktu survival pekerja. Sebelum dilakukan pemodelan, terlebih dahulu data akan dianalisis karakateristik data pekerja dengan statistika deskriptif, kurva Kaplan-Meier dan uji LogRank. Selanjutnya akan dilakukan resampling dengan bootstrap.

Kelebihan dari metode regresi cox proportional hazard adalah dalam membentuk model tidak diperlukan fungsi distribusi parametrik dan asumsi pemodelan hanya untuk memvalidasi asumsi bahwa fungsi hazard harus proporsional setiap waktu. Hal inilah yang membedakan metode ini dengan metode lainnya karena diperlukan pemeriksaan asumsi proportional hazard. Metode bootstrap memiliki kelebihan dapat digunakan untuk ukuran data yang relati kecil.

Penelitian sebelumnya dilakukan oleh Apriyanti (2018) dimana diteliti pemodelan ketahanan hidup penderita hemodialisis di RSUD kabupaten Sidoarjo dengan menggunakan metode regresi cox proportional hazard. Model ini digunakan untuk mengetahui faktor-faktor mana yang mempengaruhi transplantasi ginjal. Penelitian lainnya adalah penelitian yang dilakukan Fa'rifah (2012) untuk mengetahui faktor-faktor mana yang mempengaruhi laju kesembuhan 
pasien penderita Demam Berdarah Dengue (DBD) di rumah sakit umum haji. Penelitian sebelumnya tentang bootstrap telah dilakukan oleh Ihwah (2012) dimana dalam penelitiannya membuktikan bahwa metode bootstrap dapat mengestimasi koefisien beta pada model regresi cox proportional hazard.

\section{TINJAUAN PUSTAKA}

\section{A. Analisis Survival}

Analisis ini bertujuan menduga probabilitas kelangsungan hidup, kekambuhan, kematian, dan peristiwa-peristiwa lainnya sampai pada periode waktu tertentu. Berikut ini tiga elemen yang harus diperhatikan dalam waktu survival.

a. Time origin atau starting point.

b. Ending events of interest.

c. Measurement scale for the passage of time.

Fungsi sebaran kumulatif untuk peluang kejadian gagal sebelum waktu jangka di awal adalah sebagai berikut [4].

$$
F(y)=P(Y \leq y)=\int_{0}^{y} f(y) d t
$$

Dengan,

Y : waktu survival

$\mathrm{f}(\mathrm{y})$ : fungsi kepadatan peluang

\section{B. Tipe Penyensoran Data}

Data tersensor merupakan obyek penelitian keluar dari penelitian dikarenakan waktu hidup obyek penelitian tidak diketahui sampai terjadi sesuatu kejadian yang tidak terduga [5]. Data tersensor dibagi menjadi 3 jenis yakni :
a. Data sensor tipe I
b. Data sensor tipa II
c. Data sensor tipe III

\section{Kurva Survival Kaplan-Meier dan Uji Log-Rank}

Metode ini didasarkan pada waktu kelangsungan hidup dan data sensor diasumsikan independen berdasarkan waktu kelangsungan hidupnya. Hal ini terjadi karena penyebab failure time tidak berhubungan dengan observasi yang disensor [6]. Kurva ini digunakan untuk menggambarkan sebuah hubungan antara estimasi fungsi survival pada waktu ke-t dengan waktu survival. Estimasi fungsi tersebut dapat dibentuk menjadi persamaan berikut ini.

$$
\hat{S}\left(t_{(j)}\right)=\hat{S}\left(t_{(j-1)}\right) x \hat{P} r\left[T>t_{(j)} \mid T \geq t_{(j)}\right]
$$

Uji Log-Rank digunakan untuk melihat efisiensi perbandingan antara perawatan baru dengan perawatan lama apabila yang diukur adalah waktu hingga terjadi suatu peristiwa. Pengujian ini digunakan untuk membandingkan kurva Kaplan-Meier dalam kelompok yang berbeda [7]. Hipotesis yang digunakan dalam pengujian ini adalah sebagai berikut.

$\mathrm{H}_{0}$ : Tidak ada perbedaan antar kelompok pada kurva survival. $\mathrm{H}_{1}$ : Adanya perbedaan antar kelompok pada kurva survival. Statistik uji :

$$
\chi^{2} \approx \sum_{I=1}^{G} \frac{\left(O_{i}-E_{i}\right)^{2}}{E_{i}}
$$

$O_{i}$ : nilai observasi individu pada kelompok ke- $i$

$E_{i}$ : nilai ekspektasi individu pada kelompok ke- $i$

\section{Asumsi Proportional Hazard}

Asumsi ini terpenuhi jika mempunyai nilai hazard ratio yang konstan dengan waktunya [6]. Pengecekan asumsi ini dapat dilakukan dengan 3 pendekatan, yakni :

a. Pendekatan grafik

Grafik yang digunakan untuk penelitian survival adalah $\ln [-\ln S(t)]$ dan grafik observed versus expected.

b. Pendekatan goodness of fit

Pendekatan ini dilakukan dengan menggunakan $p$-value, apabila $p$-value lebih kecil dari taraf signiikan maka variabel yang diuji tdak memnuhi asumsi.

\section{E. Model Regresi Cox Proportional Hazard}

Model ini digunakan untuk mengetahui hubungan antara variabel dependen $(Y)$ dan independen $(X)$ melalui fungsi hazard yang berbentuk eksponensial terhadap waktu tertentu. Pemodelan tersebut dapat dituliska sebagai berikut [8].

$$
h(t, \boldsymbol{X})=h_{0}(t) \exp \left[\sum_{i=1}^{p} \beta_{i} x_{i}\right]
$$

dengan :

$$
\begin{aligned}
& h_{0}(t) \quad \text { : fungsi kegagalan dasar } \\
& \beta_{1}, \beta_{2}, \ldots, \beta_{p} \quad \text { : parameter regresi } \\
& x_{i j 1}, x_{i j 2}, \ldots, x_{i j p} \quad: \text { nilai dari variabel bebas } \\
& X_{1}, X_{2}, \ldots, X_{p} \text { subjek ke- } i \text { interval ke- } p \text {. }
\end{aligned}
$$

\section{F. Estimasi Parameter Model Cox Proportional Hazard}

Apabila terdapat $n$ obyek penelitian dengan $r$ obyek penelitian mengalami event, maka $n-r$ merupakan jumlah obyek yang tersensor dan diasumsikan hanya terdapat satu obyek yang mengalami event pada suatu waktu tertentu. Waktu survival terurut dinotasikan sebagai $t_{(I)}<t_{(2)}<\ldots<t_{(r)}$ untuk $r$ obyek penelitian yang mengalami event. Himpunan untuk obyek penelitian yang mengalami event sebelum waktu $t_{(1)}$ dinotasikan sebagai $R\left(t_{(l)}\right)$. Dari himpunan tersebut didapatkan fungsi partial likelihood dari model regresi cox proportional hazard adalah sebagai berikut.

$$
L(\beta)=\prod_{t=1}^{n} \frac{\exp \left(\boldsymbol{\beta}^{\prime} \boldsymbol{x}_{(t)}\right)}{\sum_{l \in R\left(t_{(l)}\right)} \exp \left(\boldsymbol{\beta}^{\prime} \boldsymbol{x}_{(l)}\right)}
$$

Vektor variabel dari obyek yang gagal pada waktu ke- $l$ dengan waktu $t_{(l)}$ adalah $x_{(l)}$. Obyek yang memiliki resiko gagal pada waktu ke-l dinotasikan sebagai $R\left(t_{(l)}\right)$.

Langkah selanjutnya setelah mendapatkan fungsi partial likelihood adalah memaksimumkan turunan pertama dari fungsi ln L(ק). Dalam menyelesaikan estimasi parameter perlu digunakan metode Newton-Rhapson untuk iterasi numerik karena estimasi parameter yang didapatkan implisit [5]. Jika turunan pertama fungsi $\ln \mathrm{L}(\boldsymbol{\beta})$ terhadap parameter $\boldsymbol{\beta}$ dinotasikan sebagai $\mathbf{g}(\boldsymbol{\beta})$ dengan ukuran vektor pxl. Maka turunan kedua dari fungsi ini dinotasikan dengan $\mathbf{H}(\boldsymbol{\beta})$ dengan ukuran matriks $p x p$. Dengan demikian estimasi parameter pada iterasi ke $(l+1)$ adalah sebagai berikut. 


$$
\boldsymbol{\beta}^{(l+1)}=\boldsymbol{\beta}^{l}-\boldsymbol{H}^{-1}\left(\boldsymbol{\beta}^{(l)}\right) g\left(\boldsymbol{\beta}^{(l)}\right)
$$

Iterasi Newton-Rhapson akan berhenti jika $\left\|\boldsymbol{\beta}^{(l+1)}-\boldsymbol{\beta}^{(l)}\right\| \leq \varepsilon$, dimana $\varepsilon$ merupakan suatu bilangan yang sangat kecil.

\section{G. Bootstrap}

Bootstrap merupakan metode resampling nonparametrik yang bertujuan untuk menentukan estimasi standar error dan confidence interval dari parameter populasi seperti mean, rasio, median, proporsi, koefisien korelasi atau koefisien regresi tanpa menggunakan asumsi distribusi. Metode bootstrap dapat digunakan untuk mengatasi data yang sedikit , data yang menyimpang dari asumsinya maupun data yang tidak memiliki asumsi distribusi [9]. Metode ini digunakan dengan mengambil sampel dari data asli dengan ukuran yang sama seperti data asli. Dalam metode bootstrap kedudukan data asli sama sebagai populasi. Teknik penyampelan seperti ini disebut resampling bootstrap.

\section{H. Kematian}

Jika dilihat dari segi biologis, kematian merupakan berhentinya seluruh proses aktivitas dalam tubuh pada seorang individu yang ditandai dengan hilangsnya fungsi otak, detak jantung berhenti dan lain-lain [10]. Kematian dilihat dari perspektif agama dapat diartikan sebagai peralihan kehidupan dari dunia menuju ke kehidupan lain [11]. Kematian dapat dilihat secara psikologi yaitu sebuah peristiwa yang sangat berpengaruh dalam kehidupan seseorang dimana sebagian orang menganggap kematian merupakan sebuah malapetaka namun sebagian orang lainnya mengaggap kehidupan di dunia hanya sementara karena ada kehidupan lain yang lebih mulia kelak yaitu di akhirat.

\section{METODOLOGI PENELITIAN}

\section{A. Sumber Data}

Data yang digunakan merupakan data sekunder yang diperoleh dari PT. Taspen (Persero) Kantor Cabang Utama Surabaya. Data yang digunakan merupakan bagian dari data pensiun meninggal aktif dengan periode pengambilan data Februari 2017 sampai Maret 2018 dimana data yang mengalami kematian berjumlah 60 orang pekerja. Jumlah data yang dipakai sebanyak 100 data.

\section{B. Variabel Penelitian}

Variabel yang digunakan dalam penelitian ini merupakan variabel dependen dan variabel independen. Dimana variabel dependennya merupakan waktu survival pekerja dan variabel independennya merupakan faktor-faktor yang diduga memperngaruhi variabel dependen (Tabel 1).

\section{Langkah Analisis}

Langkah analisis yang akan dilakukan dalam penelitian ini adalah sebagai berikut :

1. Mengumpulkan data dari PT. Taspen Kantor Cabang Utama Surabaya.

2. Melakukan analisis statistika deskriptif untuk mengetahui karakteristik data pekerja.
3. Menganalisis karakteristik kurva Kaplan-Meier untuk semua faktor-faktor yang mempengaruhi waktu survival pekerja.

4. Melakukan pengujian Log-Rank untuk semua faktorfaktor yang mempengaruhi waktu survival pekerja.

5. Pemeriksaan asumsi proportional hazard terhadap semua variabel independen.

6. Melakukan estimasi parameter model regresi cox proportional hazard.

7. Melakukan uji signifikansi parameter.

8. Melakuakan seleseksi variabel

9. Melakukan interpretasi model regresi cox proportional hazard.

10. Mensimulasikan data asli dengan metode bootstrap.

11. Melakukan estimasi parameter model dengan confidence interval.

12. Membuat kesimpulan dan saran dari hasil yang sudah di analisis.

Tabel 1.

Variabel Dependen dan Independen dalam Penelitian

\begin{tabular}{|c|c|c|c|}
\hline Variabel & Deskripsi & Keterangan & Skala \\
\hline$T$ & $\begin{array}{l}\text { Waktu } \\
\text { Survival }\end{array}$ & $\begin{array}{llr}\text { Waktu } & \text { dimana } & \text { seseorang } \\
\text { bekerja } & \text { sampai } & \text { meninggal } \\
\text { (tahun) } & & \\
& & \end{array}$ & Rasio \\
\hline$D$ & $\begin{array}{l}\text { Status } \\
\text { Pekerja }\end{array}$ & $\begin{array}{l}1 \text { : Data tidak tersensor ketika } \\
\text { pekerja meninggal } \\
0 \text { : Data tersensor ketika } \\
\text { pekerja belum meninggal. }\end{array}$ & Nominal \\
\hline$X_{1}$ & $\begin{array}{l}\text { Jenis } \\
\text { Kelamin }\end{array}$ & $\begin{array}{l}0: \text { Perempuan } \\
1: \text { Laki-laki }\end{array}$ & Nominal \\
\hline$X_{2}$ & $\begin{array}{l}\text { Golongan } \\
\text { Pekerja }\end{array}$ & $\begin{array}{l}0: \text { Golongan } 1 \text { dan } 2 \\
3: \text { Golongan } 3 \\
4: \text { Golongan } 4\end{array}$ & Nominal \\
\hline$X_{a}$ & Pasangan & $\begin{array}{l}0: \text { Tidak memiliki pasangan } \\
1: \text { Memiliki1 Pasangan }\end{array}$ & Nominal \\
\hline$X_{4}$ & Anak & $\begin{array}{l}0: \text { Tidak memiliki anak } \\
1: \text { Jumlah anak } 1 \\
2: \text { Jumlah anak } 2\end{array}$ & Nominal \\
\hline$X_{5}$ & Usia & $\begin{array}{l}\text { Usia seorang peserta pegawai } \\
\text { negeri sipil ketika meninggal } \\
\text { (tahun). }\end{array}$ & Rasio \\
\hline
\end{tabular}

\section{ANALISIS DAN PEMBAHASAN}

\section{A. Analisis Statistika Deskriptif}

Analisis ini digunakan untuk mengetahui karakteristik dari variabel dependen dan independenyang dipakai dalam penelitian ini. Pada variabel kontinu akan diolah dengan menggunakan sooftware Minitab dimana akan dimunculkan nilai mean, standar deviasi, nilai minimum dan maksimum.

Tabel 1.

Statistika Deskriptif untuk Data pekerja

\begin{tabular}{llrrr}
\hline \hline \multicolumn{1}{c}{ Variabel } & \multicolumn{1}{c}{$\begin{array}{l}\text { Rata- } \\
\text { Rata }\end{array}$} & $\begin{array}{l}\text { Standar } \\
\text { Deviasi }\end{array}$ & Minimal & \multirow{2}{*}{ Maximal } \\
\hline Waktu Survival & 24,575 & 9,753 & 3,408 & 39,975 \\
Usia & 52,575 & 5,927 & 30,088 & 62,532 \\
\hline \hline
\end{tabular}

Tabel 1 menunjukkan bahwa rata-rata dari variabel kontinu adalah pekerja bekerja sampai berumur 24 tahun dan usia ratarata ketika pekerja meninggal adalah 53 tahun. Minimal waktu 
survival pekerja adalah 3 tahun dan usia paling kecil ketika pekerja meninggal adalah 30 tahun. Maksimal waktu survival pekerja adalah 40 tahun dan usia paling tua adalah 63 tahun.

Berikut ini merupakan karakteristik variabel kategorik dengan menggunakan pie chart.

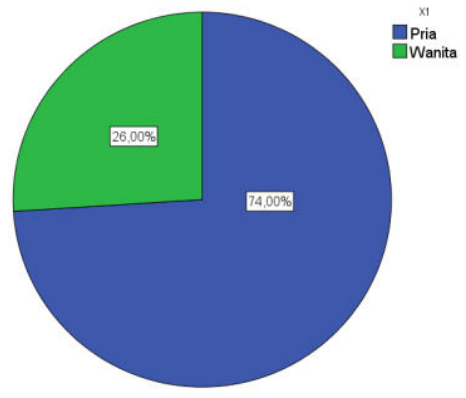

Gambar 1. Pie Chart Jenis Kelamin.

Gambar ini menunjukkan bahwa dari 100 pekerja, pekerja dengan jenis kelamin pria lebih banyak daripada wanita. Dibuktikan pada Gambar 1 bahwa pekerja dengan jenis kelamin pria sebanyak $74 \%$ dan pekerja berjenis kelamin wanita memiliki persentase $26 \%$.

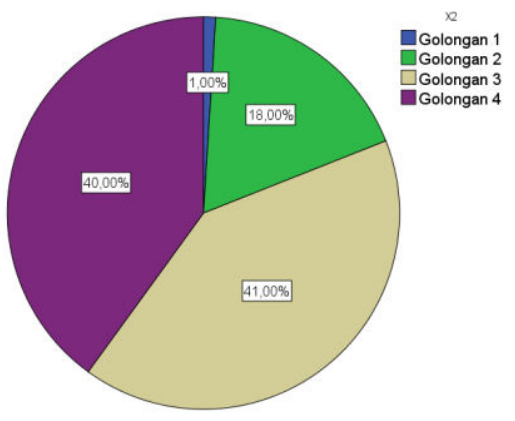

Gambar 2. Pie Chart Golongan Pekerja

Berdasarkan Gambar 2 dari 100 data, pekerja paling banyak memiliki golongan 3 dengan persentase sebesar $41 \%$. Kemudian diikuti dengan pekerja golongan 4 dengan persentase sebesar $40 \%$, lalu diikuti dengan pekerja yang memiliki golongan 2 dan 1 karena golongan 1 hanya memiliki 1 pekerja maka pekerja dengan golongan 1 akan digabungkan dengan pekerja golongan 2 .

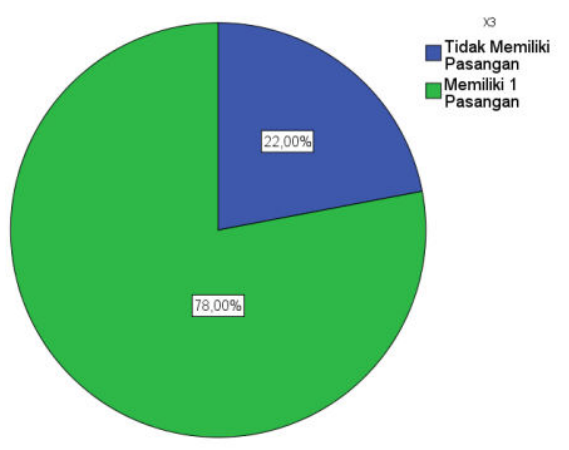

Gambar 3. Pie Chart Pasangan.

Kategori yang paling dominan pada Gambar 3 adalah pekerja yang memiliki 1 pasangan. Pekerja yang mempunyai 1 pasangan memiliki persentase sebesar $78 \%$ setara dengan 78 orang pekerja. Hal ini menunjukkan kebanyakan pekerja memiliki 1 pasangan ketika meninggal.

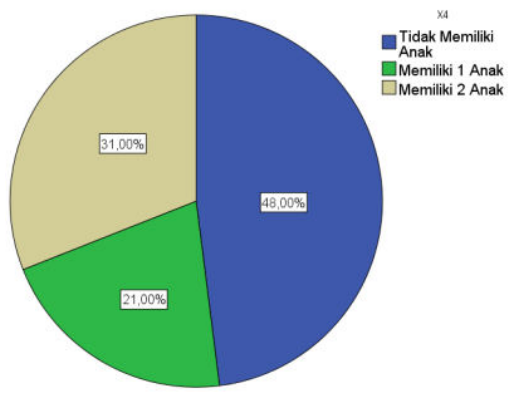

Gambar 4. Pie Chart Anak.

Gambar 4 menunjukkan bahwa pekerja yang tidak memiliki anak menempati peringkat pertama. Persentase untuk jumlah pekerja yang tidak memiliki anak sebesar $48 \%$. Sedangkan peringkat berikutnya disusul oleh pekerja yang memiliki 2 anak dengan persentase $31 \%$. Pekerja yang memiliki 1 anak memiliki persentase terkecil dengan persentase sebesar $21 \%$.

\section{B. Karakteristik Kurva Kaplan-Meier dan Uji Log-Rank}

Analisis karakteristik kurva Kaplan-Meier ini digunakan untuk mengetahui karakteritik kurva survival pekerja yang sudah meninggal berdasarkan faktor-faktor yang diduga mempengaruhi ketahanan hidup pekerja tersebut, sedangkan pengujian Log-Rank digunakan untuk membedakan grup yang berbeda dalam satu kurva survival. Berikut ini akan dievaluasi karakteristik pekerja melalui semua variabel independennya.

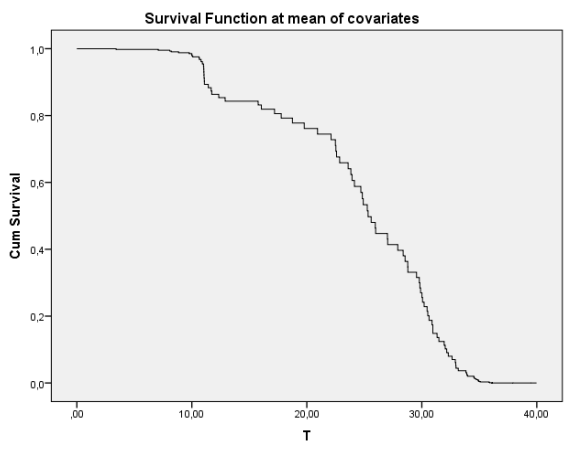

Gambar 5. Kurva Kaplan-Meier Semua Variabel Independen.

Gambar 5 menunjukkan bahwa kurva survival turun sampai pada rentan waktu 40 tahun. Hal ini menunjukkan bahwa rentang waktu 100 orang pekerja mengalami kematian adalah 40 tahun.

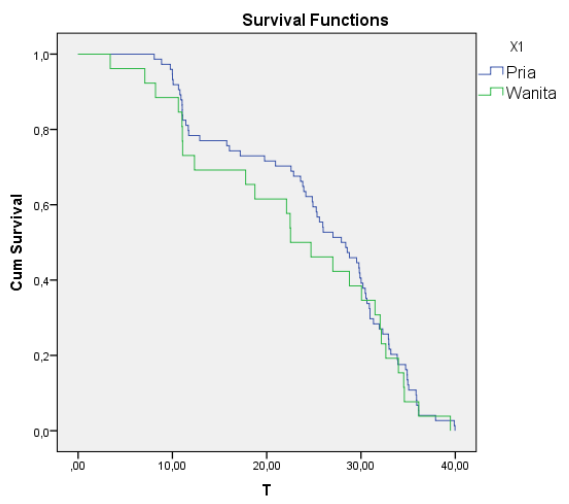

Gambar 6. Kurva Kaplan-Meier untuk Variabel Jenis Kelamin. 
Gambar 6 menunjukkan bahwa garis biru berada di atas garis hijau ini artinya tingkat kematian pekerja berjenis kelamin wanita lebih tinggi daripada pria. Selanjutnya akan dilanjutkan dengan pegujian log-rank untuk variabel jenis kelamin.

Uji log-rank pada analisis ini menggunakan taraf signifikansi 5\% yang akan dibandingkan dengan $p$-value. Jika $p$-value lebih besar dari taraf signifikan maka keputusan yang diambil gagal tolak $\mathrm{H}_{0}$. P-value sebesar 0,190 , hal ini menunjukkan bahwa $p$-value lebih besar daripada taraf signifikan. Maka dapat disimpulkan bahwa kurva survival tidak berbeda secara signifikan berdasakan faktor jenis kelamin.

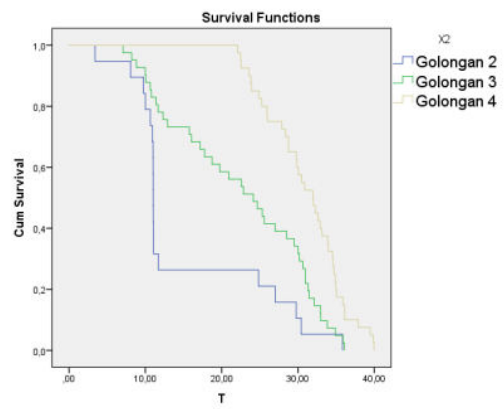

Gambar 7. Kurva Kaplan-Meier untuk Golongan Pekerja.

Gambar 7 menunjukkan bahwa pekerja dengan golongan 4 cenderung bisa bertahan hidup lebih lama daripada ketiga kategori lainnya. Selanjutnya akan diuji berdasarkan pengujian log-rank.

Pada analisis ini akan dibandingkan antara $p$-value dengan taraf signifikan sebesar 5\%. Jika $p$-value lebih besar dari taraf signifikan maka keputusan yang diambil adalah gagal tolak $\mathrm{H}_{0}$. $P$-value sebesar 0,000 , artinya $p$-value lebih kecil dari taraf signifikan. Maka dapat disimpulkan kurva survival pekerja memiliki perbedaan secara signifikan berdasarkan faktor golongan pekerja.

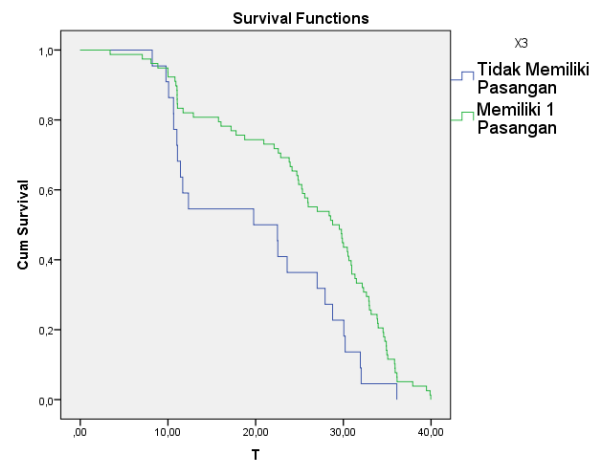

Gambar 8. Kurva Kaplan Meier Variabel Pasangan.

Gambar 8 menunjukkan bahwa garis hijau berada di atas garis biru, artinya tingkat kematian pekerja yang tidak memiliki pasangan lebih tinggi daripada pekerja yang memiliki satu pasangan. Kedua kurva tidak saling berimpit atau berpotongan, artinya diduga ada perbedaan kurva survival antara pasangan yang tidak memiliki pasangan maupun yang memiliki satu pasangan.
Hasil pendugaan ini akan dibuktikan dengan uji log-rank jika $p$-value lebih besar dari nilai taraf signifikans 5\% maka akan menghasilkan keputusan gagal tolak $\mathrm{H}_{0}$. P-value dari variabel ini adalah 0,004 lebih kecil dari taraf signifikan artinya ada perbedaan kurva survival antara pekerja yang tidak memiliki pasangan dan yang memiliki satu pasangan.

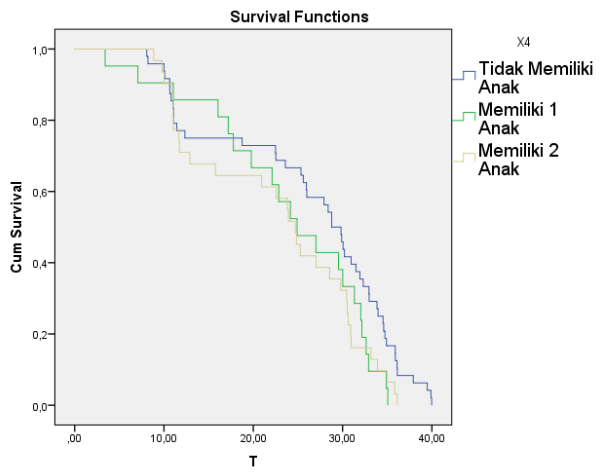

Gambar 9. Kurva Kaplan Meier Variabel Pasangan.

Berdasarkan Gambar 9 garis berwarna kuning berada di bawah garis lainnya. Hal ini menunjukkan bahwa tingkat kematian pekerja yang memiliki dua anak lebih tinggi daripada pekerja yang tidak memiliki anak dan memiliki 1 anak. Kurvakurva pada Gambar 9 terlihat saling berimpit atau berdekatan, diduga tidak ada perbedaan pada kurva survival antar kelompok variabel anak.

Kurva Kaplan-Meier pada Gambar 9 akan dibuktikan dengan $p$-value dari uji log-rank pada hasil perhitungan software SPSS. $p$-value diketahui sebesar 0,061. Jika p-value dibandingkan dengan taraf signifikan 5\% maka akan dihasilkan keputusan gagal tolak $\mathrm{H}_{0}$ yang artinya tidak ada perbedaan kurva survival antar kelompok pekerja dalam variabel anak.

\section{Model Regresi Cox Proportional Hazard}

Dalam pemodelan regresi cox proportional hazard akan diuji asumsi proportional hazard dengan menggunakan uji goodness of fit. Pemeriksaan asumsi proportional hazard ini akan menggunakan taraf signifikansi $5 \%$ bila mendapatkan keputusan gagal tolak $\mathrm{H}_{0}$ artinya asumsi terpenuhi. Dan apabila keputusan yang diambil adalah tolak $\mathrm{H}_{0}$ artinya asumsi proportional hazard tidak terpenuhi.

Tabel 2.

Hasil Goodness of Fit

\begin{tabular}{lr}
\hline \hline Variabel & $P$-Value \\
\hline Jenis Kelamin (1) & 0,0300 \\
Golongan Pekerja (2) & 0,1680 \\
Golongan Pekerja (3) & 0,0156 \\
Pasangan (1) & 0,2822 \\
Anak (1) & 0,8306 \\
Anak (2) & 0,3361 \\
Usia & 0,9977 \\
\hline \hline
\end{tabular}

Berdasarkan Tabel 2 didapatkan hasil bahwa variabel jenis kelamin memiliki keputusan tolak $\mathrm{H}_{0}$ karena $p$-value lebih kecil dari taraf signifikan. Sedangkan $p$-value variabel lainnya lebih besar dari taraf signifikannya sehingga keputusan yang diambil adalah gagal tolak $\mathrm{H}_{0}$. 
Tabel 3.

Hasil Goodness of Fit Tanpa Variabel Jenis Kelamin

\begin{tabular}{ccr}
\hline \hline & Variabel & P-Value \\
\hline Golongan (2) & & 0,08648 \\
Golongan (3) & & 0,00225 \\
Pasangan (1) & 0,32765 \\
Anak (1) & & 0,43845 \\
\hline \multicolumn{2}{c}{ Variabel } & P-Value \\
\cline { 2 - 3 } & Anak (2) 0,60655 \\
\multicolumn{2}{c}{ Usia } & 0,38740 \\
\hline \hline
\end{tabular}

Pengujian proporsional hazard tanpa menggunakan variabel jenis kelamin pada Tabel 3 menghasilkan keputusan gagal tolak $\mathrm{H}_{0}$ karena $p$-value melebihi taraf signifikan sehingga faktor golongan pekerja, pasangan, anak dan usia memenuhi asumsi proporsional hazard. Maka dapat disimpulkan bahwa faktor-faktor tersebut yang diduga mempengaruhi waktu survival pekerja tidak memiliki korelasi yang besar dengan waktu survival pekerja. Selanjutnya akan dilakukan estimasi parameter dengan menggunakan variabelvariabel tersebut.

Tabel 4.

Estimasi Parameter Model Cox Proportional Hazard

\begin{tabular}{lrr}
\hline \hline \multicolumn{1}{c}{ Variabel } & Parameter $(\beta)$ & \multicolumn{1}{c}{-Value } \\
\hline Golongan (2) & 0,7941 & 0,050969 \\
Golongan (3) & 0,7389 & 0,016066 \\
Pasangan (1) & $-1,188$ & 0,000349 \\
Anak (1) & 0,2475 & 0,480159 \\
Anak (2) & 0,5865 & 0,079806 \\
Usia & $-9,375.10-11$ & 0,296990 \\
\hline Likelihood Ratio & 23,57 & 0,0006251 \\
\hline \hline
\end{tabular}

Berdasarkan Tabel 4 akan dilakukan uji serentak dengan menggunakan $p$-value dari likelihood ratio dimana nilai didapatkan sebesar 0,0006251. $P$-value ini akan dibandingkan dengan taraf signifikansi 5\% dimana jika $p$-value kurang dari taraf signifikannya maka akan diperoleh keputusan tolak $\mathrm{H}_{0}$. Dari ketentuan tersebut maka dapat diambil keputusan tolak $\mathrm{H}_{0}$. Dengan demikian dapat disimpulkan bahwa minimal ada satu variabel independen yang berpengaruh secara signifikan terhadap model. Pengujian ini akan dilanjutkan dengan uji parsial dimana akan dilihat $p$-value dari setiap parameternya. $p$-value ini akan dibandingkan dengan dengan taraf signifikan $5 \%$, apabila $p$-value lebih kecil dari taraf signifikan keputusan yang diambil adalah tolak $\mathrm{H}_{0}$. Dari Tabel 4 terlihat bahwa $p$ value yang lebih kecil dari taraf signifikan masih banyak. Maka akan dilakukan eliminasi backward dengan menggunakan kriteria AIC dimana akan dicari nilai AIC terkecil. Nilai AIC terkecil sebesar 441,16 dengan model terbentuk dari variabel golongan dan pasangan.

Tabel 5. dapat menunjukkan nilai estimasi parameternya setelah diseleksi sehingga didapatkan model cox proportional hazard terbaik sebagai berikut.

$$
h(t)=h_{0}(t) \exp \left(-0,1934 X_{2(3)}-1,0292 X_{2(4)}-1,0651 X_{3(1)}\right)
$$

Dari model tersebut akan dilanjutkan pengujian serentak dengan menggunakan nilai $p$-value likelihood ratio pada Tabel 5. Nilai $p$-value kurang dari taraf signiikan artinya minimal ada satu variabel yang berpengaruh. Selanjutnya dengan uji parsial dimana pengujian ini menggunakan $p$-value apabila $p$-value kurang dari taraf signifikan maka variabel berpengaruh terhadap model. Pada Tabel 5 variabel yang berpengaruh adalah golongan 4 dan pasangan. Interpretasi model regresi cox proportional hazard akan dilakukan menggunakan nilai exp $(\beta)$. Pekerja dengan golongan 4 memiliki resiko 0,3573 kali untuk meninggal daripada pekerja dengan golongan 1\&2. Selain interpretasi dari variabel golongan, selanjutnya akan dilakukan interpretasi variabel pasangan. Pekerja yang mempunyaii 1 pasangan memiliki resiko 0,3447 kali untuk meninggal daripada pekerja yang tidak memiliki pasangan.

Tabel 5.

Estimasi Parameter Model Terbaik

\begin{tabular}{lccccc}
\hline \hline \multicolumn{1}{c}{ Variabel } & $\begin{array}{c}\text { Parameter } \\
(\beta)\end{array}$ & \multirow{2}{*}{$\operatorname{Exp}(\beta)$} & $\begin{array}{c}\text { Standar } \\
\text { Error }\end{array}$ & $\begin{array}{c}\text { Statistik } \\
\text { Uji }\end{array}$ & $P$-Value \\
\hline Golongan $(3)$ & $-0,1934$ & 0,8241 & 0,3628 & 0,28417 & 0,59398 \\
Golongan (4) & $-1,0292$ & 0,3573 & 0,3899 & 6,96775 & 0,00830 \\
Pasangan $(1)$ & $-1,0651$ & 0,3447 & 0,3065 & 12,07591 & 0,00051 \\
\hline Likelihood & & & & 19,78 & 0,00019 \\
Ratio & & & & & \\
\hline \hline
\end{tabular}

\section{Analisis Regresi Cox Proportional Hazard dengan Menggunakan Metode Bootstrap}

Proses bootstrap dalam analisis ini dilakukan dengan cara mengambil acak sampel da Kemudian hasil perulangan tersebut akan dicari parameter untuk setiap perulangan dengan menggunakan regresi cox proportional hazard. Parameterparameter yang sudah didapatkan akan dirata-rata dan dicari confidence interval-nya. ta baru dengan menggunakan data asli secara berpasangan.

Tabel 6.

Confidence Interval 95\% dari Parameter dengan Metode Bootstrap

\begin{tabular}{cccc}
\hline \hline Variabel & $\begin{array}{c}\text { Confidence } \\
\text { Interval }\end{array}$ & $\begin{array}{c}\text { Parameter } \\
(\beta)\end{array}$ & $\begin{array}{c}\text { Exp } \\
(\beta)\end{array}$ \\
\hline Golongan (3) & {$[-0,20 ;-0,18]$} & $-0,19$ & 0,826 \\
Golongan (4) & {$[-1,13 ;-1,10]$} & $-1,11$ & 0,329 \\
Pasangan (1) & {$[-1,19 ;-1,17]$} & $-1,18$ & 0,307 \\
\hline \hline
\end{tabular}

Tabel 5 menunjukkan bahwa semua parameter tidak memuat nilai nol sehingga dapat disimpulkan bahwa semua parameter signifikan. Model yang terbentuk dari parameter-parameter tersebut adalah sebagai berikut.

$$
h(t)=h_{0}(t) \exp \left(-0,19 X_{2(3)}-1,11 X_{2(4)}-1,18 X_{3(1)}\right)
$$

Pekerja dengan golongan 3 memiliki resiko 0,826 kali untuk meninggal daripada pekerja dengan golongan $1 \& 2$. Selain itu pekerja dengan golongan 4 memiliki resiko 0,329 kali untuk meningal daripada golongan $1 \& 2$. Variabel pasangan memiliki nilai eksponen koefisien sebesar 0,307 sehingga dapat diinterpretasikan bahwa pekerja yang tidak mempunyai pasangan memiliki resiko 0,307 kali untuk meninggal daripada pekerja yang mempunyai satu pasangan. Dalam metode ini hasil parameter yang signifikan cocok dengan data yang diberikan oleh PT.Taspen Kantor Cabang Utama Surabaya..

\section{KESIMPULAN DAN SARAN}

Hasil karakteristik data pekerja adalah pekerja mampu bertahan hidup hingga berumur 63 tahun dengan rata-rata waktu survival pekerja adalah 24 tahun. Kurva Kaplan-Meier untuk semua variabel menurun sampai pada rentang waktu 40 
tahun. Berdasarkan uji log-rank pada variabel golongan pekerja dan pasangan memiliki perbedaan kurva survival antar kelompok dalam variabelnya. Sedangkan kurva survival antar kelompok dalam variabel jenis kelamin dan anak tidak memiliki perbedaan. Faktor yang berpengaruh terhadap model regresi cox proportional hazard adalah variabel golongan 4 dan pasangan. Sedangkan jika menggunakan metode bootstrap dengan regresi cox proportional hazard, variabel-variabel yang telah diseleksi berpengaruh terhadap model.

\section{DAFTAR PUSTAKA}

[1] J. Santrock, Perkembangan Masa Hidup, 5th ed. Jakarta: Erlangga, 2002.

[2] E. Gonzalez-Mule and B. Cockburn, "Worked to Death: The Relationships of Job Demands and Job Control with Mortality," Pers. Psychol., vol. 20, no. 1, 2016.
[3] R. Chiu and Vigod, "Mortality in single fathers compared with single mothers and partnered parents: a population-based cohort study," Lancet Public Heal., pp. 2468-2667, 2018.

[4] E. Lee, Statistical Methods for Survival Data Analysis. California: Life Learning Publications Belmont, 1980.

[5] D. Collet, Modeling Survival Data in Medical Research. London: Chapman \& Hall/CRC, 2003.

[6] Kleinbaum and Klein, Survival Analysis. London: Springer Science Business Media, Inc, 2005.

[7] K. Klein, Survival Analysis. New York: Springer, 2012.

[8] D. Cox, "Regression Models and Life Tables (with Discussion)," $J$. R. Stat. Soc., 1972.

[9] S. Sahinler and D. Topuz, "Bootstrap and Jacknife Resampling Algorithms for Estimation of Regression Parameters," 2007.

[10] A. Hasan, Aplikasi Strategi Dan Model Kecerdasan Spiritual (SQ) Rasulullulah diMasa Kini. Yogyakarta: IRCiSod, 2006.

[11] N. Dister, Pengantar Psikologi Agama: Pengalaman dan Motivasi Beragama. Jakarta: Leppenas, 1982. 